the rates of the chemical reactions depend on the temperature and; (b) the amount of biogenic VOC emissions is increasing when the temperature is increasing. The impacts of climate change on the $\mathrm{BL}$ height, wind speed and relative humidity may also influence the obtained ozone concentration patterns.

\section{Conclusions}

The main goal of this study was to investigate the impact of climate change on air quality in Portugal under the IPCC SRES A2 scenario. Numerical simulations performed with the MM5/CHIMERE modelling system in Portugal indicated considerable changes in the atmospheric $\mathrm{O}_{3}$ and $\mathrm{PM}_{10}$ concentrations under the SRES A2 climatic scenario.

For the future IPCC SRES A2 scenario $\mathrm{O}_{3}$ monthly mean levels in the atmosphere may increase by almost $20 \mu \mathrm{g} \cdot \mathrm{m}^{-3}$ in Portugal in July. This estimate only considers the impact of climate change since the anthropogenic emissions were kept constant. The $\mathrm{PM}_{10}$ levels in the atmosphere will also be deeply impacted, depending on the region and the month. Throughout Portugal, the maximum increases are foreseen for the northern costal region in September reaching almost $30 \mu \mathrm{g} \cdot \mathrm{m}^{-3}$.

Overall, climate change alone may deeply impact the $\mathrm{O}_{3}$ and the $\mathrm{PM}_{10}$ levels in the atmosphere. The changes in the meteorological variables that are mostly related to the advection and transformation of these pollutants impact their atmospheric concentrations. Thus, emission changes should not be the only variable to take into consideration in this kind of study. The changes in the boundary layer height, relative humidity, temperature, solar radiation, wind speed and precipitation may be responsible for significant differences in pollutant concentration patterns. In the scope of the air quality management for next decades it is necessary to include climate change and changes in climate variability when defining longterm plans and measures to improve the quality of the air we're breathing. All the forecasted changes in the pollutant concentrations must be viewed as trend indicators due to the uncertainty inherent to this type of study.

\section{Acknowledgements}

The authors thank the Portuguese Foundation for Science and Technology for the Ph.D. grant of A. Carvalho (SFRH/BD/10882/2002) and David Hein at the Met Office Hadley Centre, U.K., for the HadAM3P climate simulations. The support from the ACCENT Network of Excellence (GOCE/CT/2004/505337) and the EU-COST 728 Action are also acknowledged.

\section{References}

Atkinson, R., Peacock, J., Marston L., Konstantinou, K., Anderson, H.R., 2004 Meta-analysis of time series studies and panel studies of particulate matter (PM) and ozone $\left(\mathrm{O}_{3}\right)$. Report of a WHO task group. Copenhagen, WHO Regional Office for Europe.

Bessagnet, B., Hodzic, A., Vautard, R., Beekmann, M., Cheinet, S., Honore, C. Liousse, C., Rouil, L., 2004. Aerosol modeling with CHIMERE Preliminary evaluation at the continental scale. Atmospheric Environment 38, $2803-2817$.

Gauss, M., Myhre, G., Isaksen, I.A., Grewe, V., Pitari, G., Wild, O., et al., 2006. Radiative forcing since preindustrial times due to ozone change in the troposphere and the lower stratosphere. Atmospheric Chemistry and Physics 6, 575 - 599

GENEMIS (Generation and Evaluation of Emission Data), 1994. EUROTRAC Annual Report - 1993 - Part 5. EUROTRAC International Scientific Secretariat: Garmisch-Partenkirchen.

Grell, G. A., J. Dudhia, and D. R. Stauffer, 1994. A description of the fifthgeneration Penn State/NCAR Mesoscale Model (MM5), NCAR Tech. Note, NCAR/TN-398+STR, 122pp.

Goswami, E., Larson, T., Lumley, T., Liu, L., 2002. Spatial characteristics of fine particulate matter: identifying representative monitoring locations in Seattle, Washington. Journal Air Waste Management 52(3), 324 - 333.

Hauglustaine, D. A., J. Lathire, S. Szopa, and G. A. Folbert, 2005. Future tropospheric ozone simulated with a climate-chemistry-biosphere model. Geophysics Research Letters 32, L24807, doi:10.1029/2005GL024031.

Hogrefe, C., Biswas, J., Lynn, B., Civerolo, K., Ku, J.Y., Rosenthal, J. et al., 2004 Simulating regional-scale ozone climatology over the eastern United States: model evaluation results. Atmospheric Environment 38, 26272638.

IPCC (Intergovernmental Panel on Climate Change), 2007. Climate Change 2007 The Physical Science Basis. Contribution of Working Group I to the Fourth Assessment Report of the Intergovernmental Panel on Climate Change. In: Solomon S., Qin D, Manning M., Chen Z., Marquis M., Averyt K.B., Tignor M. and Miller H.L. (Eds.), Cambridge University Press, Cambridge.

Jones, R.G., Murphy, J.M., Hassel, D.C., Woodage, M.J., 2005. A high resolution atmospheric GCM for the generation of regional climate scenarios. Hadley Center Technical Note 63. Exeter, UK: Met Office.

Langner, J., Bergström, R., Foltescu, V., 2005. Impact of climate change on surface ozone and deposition of sulphur and nitrogen in Europe. Atmospheric Environment 39, 1129-1141.

Monteiro, A., Miranda, A.I., Borrego, C., Vautard, R., Ferreira, J., Perez, A.T., 2007. Long-term assessment of particulate matter using CHIMERE model. Atmospheric Environment 41, 7726-7738.

Schmidt, H., Derognat, C., Vautard, R., Beekmann, M., 2001. A comparison of simulated and observed ozone mixing ratios for the summer of 1998 in Western Europe. Atmospheric Environment 35(36), 6277- 6297.

Semazzi, F., 2003. Air quality research: perspective from climate change modelling research. Environment International 29, 253-261.

Vestreng, V., 2003. Review and revision of emission data reported to CLRTAP. EMEP Status Report.

Zlatev, Z., 2007. Comprehensive Air pollution studies by the Danish Eulerian Model. Air, Water and Soil Quality Modelling for Risk and Impact Assessment. In: Ebel A, Davitashvili T (Eds.), Nato Science for Peace and Security Series C - Environmental Security, 293-302.

\title{
Sea Surface Temperature Similarities during the Present and Past Interglacials
}

\author{
Teresa Rodrigues $^{1,3}$, Fátima G. Abrantes ${ }^{1}$, Antje H. L. Voelker ${ }^{1,3}$ and Joan O. Grimalt ${ }^{2}$ \\ ${ }^{1}$ LNEG - National Laboratory for Energy and Geology, Marine Geology Unit, Alfragide, Apartado 7586, 2720-866 Amadora, Portugal \\ ${ }^{2}$ Department of Environmental Chemistry, Institute of Environmental Assessment and Water Research (ID/EA-CSIC), c/ Jordi Girona 18-26, E- \\ 08034 Barcelona, Spain \\ ${ }^{3}$ CIMAR - Centre of Marine and Environmental Research Associate Laboratory, Rua dos Bragas, 289, 4050-123 Porto, Portugal
}

Today we live in an interglacial period that started about 11,000 years ago. Interglacials occurred alternated with the longer glacial periods. Forecasting the future climatic evolution of the current interglacial period is a great challenge. Therefore it is necessary to determine the evolution of past interglacials and evaluate the response of the different components of the Earth's climatic system (Desprat et al., 2007). For a long period, paleoceanographic studies have considered that Marine Isotope Stage (MIS) 11 (400,000 $\mathrm{yr}$ ago) is a better analogue of our current status than any other more recent interglacial due to the similar orbital situation. 
Accordingly, recent studies have shown similarities between the Holocene and MIS11 records (Abreu et al., 2003; EPICA, 2004; Loutre and Berger, 2003; McManus et al., 2003; Ruddiman, 2005). However, MIS 11 stands out as unique since it exhibits warm climatic conditions for an interval of at least 30 $\mathrm{ka}$, a duration twice as long as the most recent interglacial stages (Loutre and Berger, 2003; McManus et al., 2003). But sea level, ocean temperature, salinity and ice isotopic composition were similar to those of the Holocene (McManus et al., 2003). The comparison of MIS 1 and MIS 11 will change depending on the astronomical analogy used for comparison. Synchronization of the two intervals using the precessional variations in insolation at $65^{\circ} \mathrm{N}$ shows that the present should correspond to 398 ka (Loutre, 2003; Loutre and Berger, 2003). The precessional alignment suggests that the Holocene is near its end while the obliquity alignment suggests that it will take 12 ka more to run its course, in the absence of anthropogenic interferences (Tzedakis, 2009). Aligning terminations I and $\mathrm{V}$ in the $\delta D$ of Epica Dome $C$ record suggests that today should correspond to $\sim 407 \mathrm{ka}$ within MIS 11 (EPICA, 2004). A better understanding of climatic variations during MIS 11 (430 to 360 $\mathrm{ka}$ ), is needed for a global understanding of climate change during interglacials as well as to foresee future climate change. Furthermore, this period is also important to understand the transition periods (Terminations) such as glacial to interglacial transitions.

Following this idea, we reconstruct Sea Surface Temperature (SST) conditions for the MIS 11 and for the Holocene in the Iberian Margin, an important area where the signal of the two hemispheres has been recorded (Shackleton et al., 2000).

Previously published data has proven that the surface conditions in the Iberian margin reflect the global signal and show the variability than seen in the Greenland ice cores for the last two climate cycles (Martrat et al., 2007; Rodrigues et al., submitted). For this study we use core MD03-2699 retrieved from the Estremadura Spur north of Lisbon at 1850m water depth for the MIS 11, while the Holocene reconstruction is based on two sediment sequences: 1) Estremadura MD032699 in conjunction with box core PO287-44B; and 2) core D13882, D13902 and box core PO287-26B from the Tagus prodelta off Lisbon, collected at $90 \mathrm{~m}$ water. SST was estimated from the relative composition of $\mathrm{C}_{37}$ unsaturated alkenones $\left(\mathrm{U}^{\mathrm{k}^{\prime}}{ }_{37}=0.03{ }^{*} \mathrm{SST}+0.044 ; \mathrm{r}^{2}=0.96 ; n=370\right.$ (Müller et al., 1998), following the procedures described in Villanueva (Villanueva, 1996). Briefly, sediment samples were freeze-dried and extracted by sonication using dichloromethane. The extracts were hydrolyzed with $6 \%$ potassium hydroxide in methanol to eliminate interferences from wax esters. The neutral lipids were extracted with hexane and evaporated to dryness under a $\mathrm{N}_{2}$ stream. Finally, after being derivatised with bis(trimethylsilyl)trifluoroacetamide, the extracts were analyzed with a Varian Gas chromatograph Model 3400 equipped with a septum programmable injector and a flame ionization detector. Selected samples were examined by GC-mass spectrometry (MS) for confirmation of compound identification and evaluation of possible co-elutions.

According to the SST profile for the last $6^{\text {th }}$ climatic cycles the similarities between the MIS 11 and the present interglacial are clear (Rodrigues, 2009). The orbital parameters, the eccentricity is minimum during the MIS 11 and the Holocene, the insolation at $37^{\circ} \mathrm{N}$ is the same during both periods and the precession also shows similar values. The sea level reconstructions show that $410 \mathrm{kyr}$ ago the level is similar to the level of the last 10 $\mathrm{kyr}$, including the present days. The volume of Ice represented by the marine $\delta^{18} \mathrm{O}$ also gives the idea of similar values during the MIS 11 and the Holocene. That is, in terms of SST, MIS 11 conditions were not significantly different from those registered during the elapsed portion of the Holocene (Fig. 1). Termination $\mathrm{V}$ (transition from MIS12 to MIS11) is recorded by a SST rise of $6^{\circ} \mathrm{C}$ in $1 \mathrm{ka}$. During the MIS 11 SST is in the order of $18^{\circ} \mathrm{C}$ increasing to $19^{\circ} \mathrm{C}$ after $415 \mathrm{ka}$, but followed by a decreasing tendency, more evident after $400 \mathrm{ka}$, with temperatures dropping to $13^{\circ} \mathrm{C}$.

Calendar Age (kyr BP)

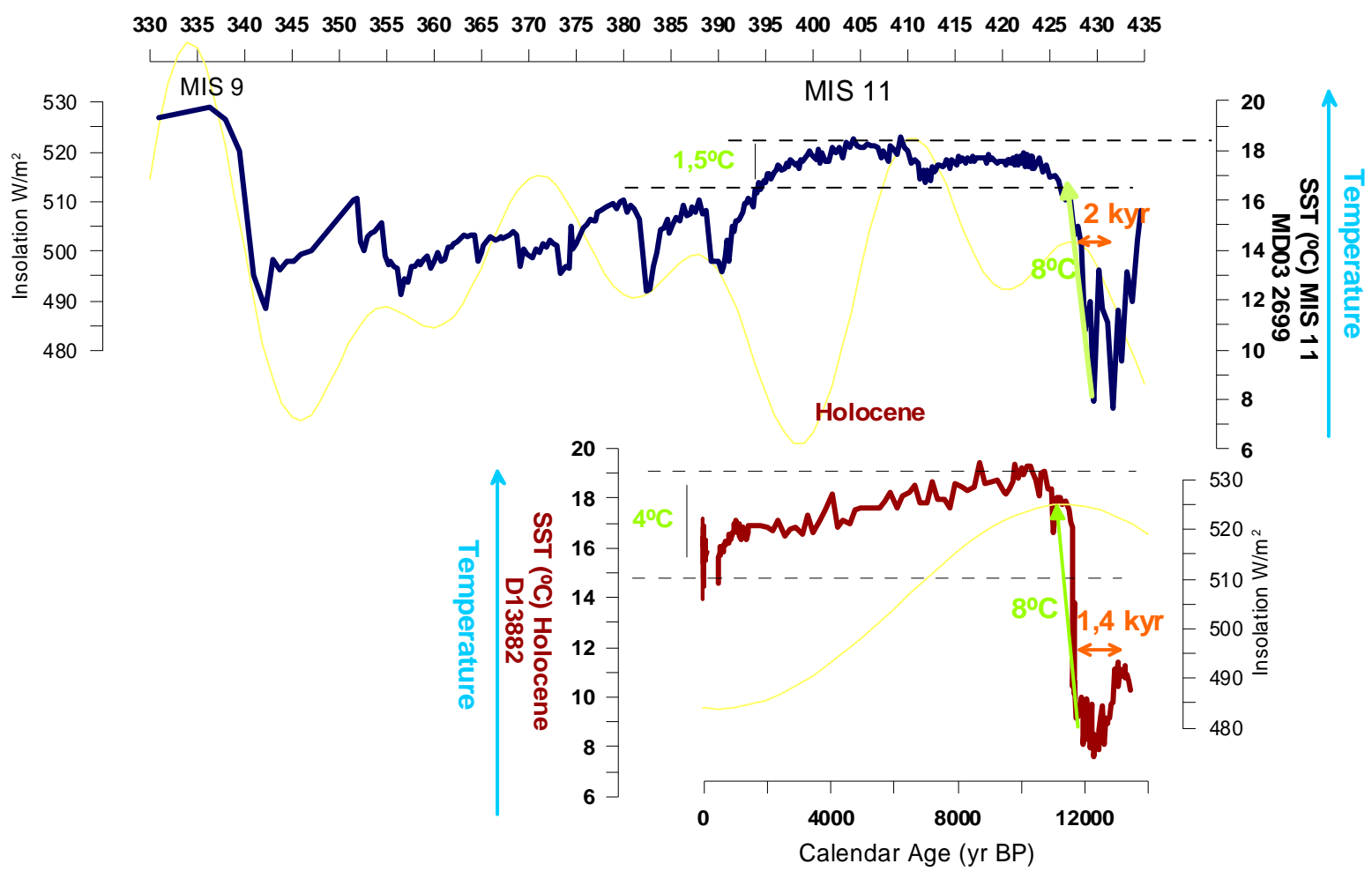

Figure 1. Sea Surface Temperature records for the Marine Isotope Stage 11 and transitions V, and MIS 1. In the Portugal Estremadura Spur core MD03 2699 
For the Holocene, the Younger Dryas / Holocene transition is registered as an abrupt change of $8^{\circ} \mathrm{C}$ in 280yr (Rodrigues et al submitted.), and the Holocene SST profile shows a $4^{\circ} \mathrm{C}$ temperature decrease between the climatic optimum (10.5 - 9.7 kyr ago) and the modern level (Fig. 1). Besides, on a century scale, there is a $2^{\circ} \mathrm{C}$ variability that allows a clear identification of the most recent and well documented climatic changes of the Northern Atlantic, the Medieval Warm Period (MWP) and the Little Ice Age (LIA) (Rodrigues et al., 2009).

If compared, Holocene maximum SST was close to $19^{\circ} \mathrm{C}$ and occurred between 10.5 and $9.7 \mathrm{ka}$ while MIS 11 record reveals two warm phases: the first with maximum SST close to $18^{\circ} \mathrm{C}$ (427 to $412 \mathrm{ka}$ ) and a second with temperatures close to $19^{\circ} \mathrm{C}$ (407 to $395 \mathrm{ka}$ ). Both periods display a SST decrease following the maximum. However, in the case of MIS 11, that decrease was interrupted by the second SST increase along with the sea level high stand at $407 \mathrm{ka}$. SST shows a amplitude of $1.5^{\circ} \mathrm{C}$ for long-term interglacial variability in both periods at the Estremadura site MD03-2699, and the maximal SSTs are associated with the insolation maximum during the respective interglacial, i.e. at the beginning of both the Holocene and MIS 11 , implying that hydrographic conditions must have been similar during both periods.

If we further compare the SST of these two periods and try different alignments, by precession, by the beginning of terminations $I$ and $V$ (Fig. 2A) or by the maximum obliquity (Fig. $2 \mathrm{~B})$, as a possible assessment of MIS 11 as a possible model for the future Holocene evolution, it becomes clear that the present conditions fit in the beginning of the MIS 11 interglacial conditions. However, the forthcoming climate conditions of the Holocene remain an open question.
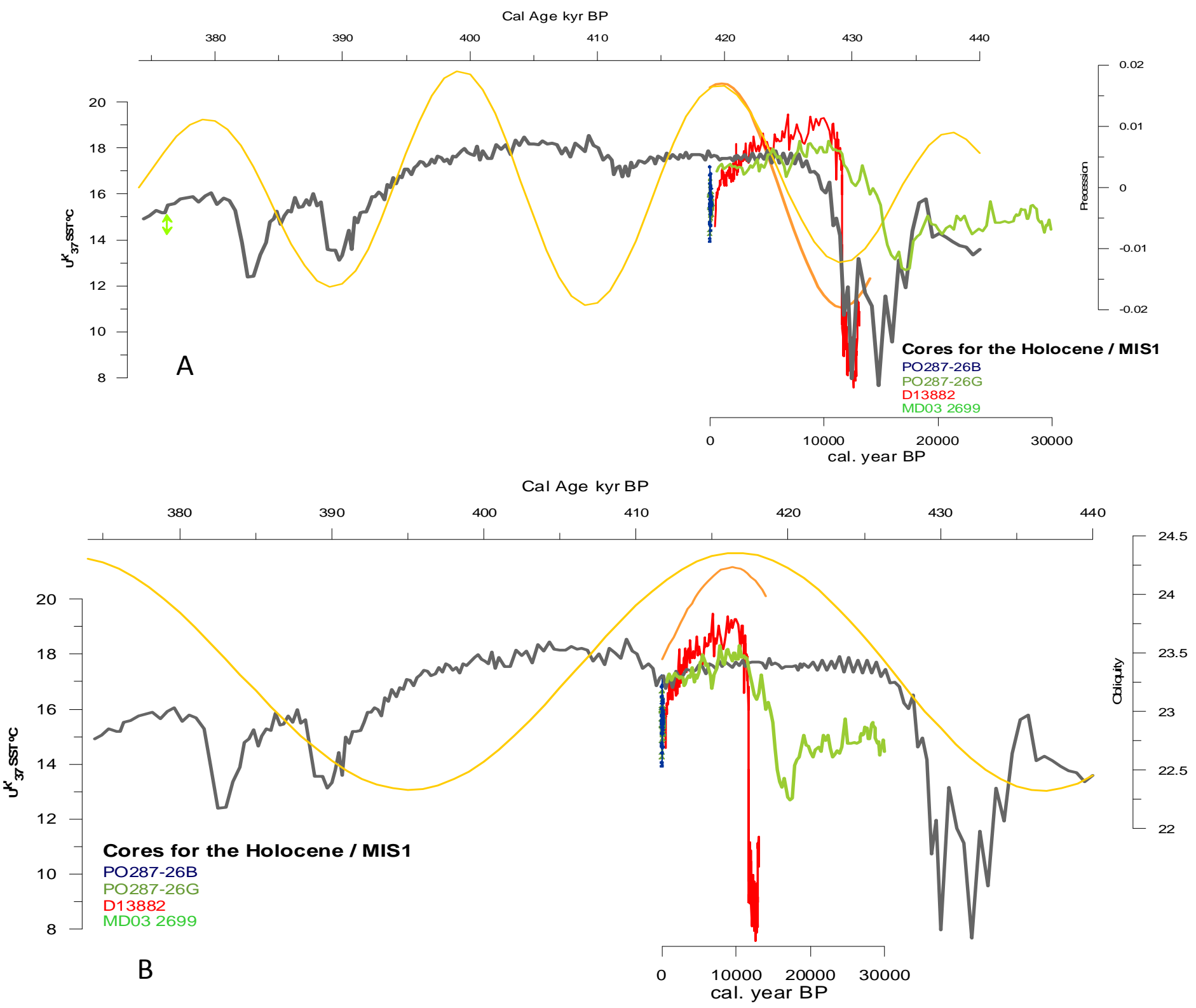

Figure 2. SST comparison between MIS11 and MIS1 using a precession alignment (A) and an obliquity alignment (B)

\section{References}

Abreu, L.d., Schonfeld, J., Vautravers, M., Shackleton, N.J. and Abrantes, F 2003. High-frequency ocean variations off the Western Iberian Margin during an extreme interglacials: is early MIS 11 equivalent to the Holocene?, AGU-EGS-EUG. Joint assembly AGU-EGS_EUG, Nice.
Desprat, S., Sánchez Goñi, M.F., Naughton, F., Turon, J.-L., Duprat, J., Malaizé, B., Cortijo, E. and Peypouquet, J.-P., 2007. Climate variability of the last five isotopic interglacials: direct land-sea.ice correlation from the multiproxy analysis of north western Iberian margin deep-sea cores. In: F. Sirocko, M. Claussen, M.F.S. Goñi and T. Litt (Editors), The climate of the past interglacials. Elsevier. 
EPICA, c.m., 2004. Eight glacial cycles from an Antartic ice core. Nature 429.

Loutre, M.F., 2003. Clues from MIS 11 to predict the future climate a modelling point of view. Earth and Planetary Science Letters 212, 213-224.

Loutre, M.F. and Berger, A., 2003. Marine Isotope Stage 11 as an analogue for the present interglacial. Global and planetary change 762, 1-9.

Martrat, B., Grimalt, J.O., Shackleton, N.J., Abreu, L.d., Hutterli, M.A. and Stocker, T.F., 2007. Four Climate Cycls of Recurring Deep and Surface Water Destabilizations on the Iberian Margin. Science 317(1139994), 502-507.

McManus, J., Oppo, D., Cullen, J. and Healey, S., 2003. Marine Isotope Stage 11 (MIS 11): Analog for Holocene and Future Climate?

Müller, P., Kirst, G., Ruhland, G., Storch, I.v. and Rosell-Melé, A., 1998. Calibration of the alkenone index Uk'37 based on core-tops the eastern South Atlantic and global ocean $\left(60^{\circ} \mathrm{N}-60^{\circ} \mathrm{S}\right)$. Geochimica et Cosmochimica Acta 62, 1757-1772.

Rodrigues, T., 2009. High-resolution Climate Study of the Past $(570,000$ to 300,000 years) and Present Interglacial in the Iberian Margin: a biomarkers view, Universitat Politècnica De Catalunya, Barcelona, 325 $\mathrm{pp}$
Rodrigues, T., Grimalt, J.O., Abrantes, F., Flores, J.A. and Lebreiro, S., 2009. Holocene interdependences of changes in sea surface temperature, productivity, and fluvial inputs in the Iberian continental shelf (Tagus mud patch). Geochemistry Geophysics Geosystems 10.

Rodrigues, T., Grimalt, J.O., Abrantes, F., Naughton, F. and Flores, J.-A., submitted. The last glacial-interglacial transition (LGIT) in the western mid-latitudes of the North Atlantic: abrupt sea surface temperature change and sea level implications.

Ruddiman, W.F., 2005. Cold climate during Stage 11 anlog to recent Millennia. Quaternary Science Reviews 24, 1111-1121.

Shackleton, N.J., Hall, M.A. and Vincent, E., 2000. Phase relationships between millennial-scale eventes 64,000-24.000 years ago. Palaeogeography 15(6), 565-569.

Tzedakis, P.C., 2009. The MIS 11 - MIS 1 analogy, southern European vegetation, atmospheric methane and the "early anthropogenic hypothesis". Climate of The Past Discussions 5, 1337-1365.

Villanueva, J., 1996. Estudi de les variaciones climàtiques i oceanogràfiques a l'atlantic Nord Durant els últims 300.000 anys mitjançant I'análisi de marcadores moleculars., Ramon Llull, Barcelona, 186 pp.

\title{
The Effect of Tidal Altitude on Methane Gas Bubbling from the Sediments of the Ria of Aveiro
}

\author{
Henrique Duarte ${ }^{1,2}$ and Luís Pinheiro ${ }^{3}$ \\ ${ }^{1}$ LNEG - National Laboratory for Energy and Geology, Marine Geology Unit, Alfragide, Apartado 7586, 2720-866 Amadora, Portugal \\ ${ }^{2}$ CIIMAR - Interdisciplinary Center of Marine and Environmental Research, Rua dos Bragas, 289, 4050-123 Porto, Portugal \\ ${ }^{3}$ Departamento de Geociências, Universidade de Aveiro, Campus de Santiago, 3810-193 Aveiro, Portugal
}

The study of gas occurrence and seepage in sedimentary basins, mainly methane, is of significant interest for its role as a greenhouse gas and potential contribution to climate changes (Hovland et al., 1993; Houghton et al., 2001; Etiope, 2004; Judd, 2004), as an important energy source and as a cause of natural hazards (Best et al., 2006). According to Best (2006), understanding these roles of methane gas requires the development of models of methane gas generation and gas fluxes, as well as the acquisition of reliable model input data, such as sediment accumulation rates, organic matter concentrations, amount of gas present, sediment shear strength, etc. Considering that the organic rich muddy sediments of estuaries and coastal lagoons are prime sources of methane gas (Kelley et al., 1995; Van der Nat and Middelburg, 2000), modern day estuaries and coastal lagoons are preferential objects for these studies on shallow methane gas generation and evaluation of gas fluxes to the atmosphere (Garcia-Gil, 2003; Duarte et al., 2007).

The Ria of Aveiro is a recent barrier-lagoon system composed of a complex network of tidal channels, tidal flats, salt marshes and supra-tidal sand isles, located along the northwest Portuguese coast. The semi-diurnal tidal cycle is the strongest forcing mechanism in the dynamics of the Ria of Aveiro. The small water volume at low spring tides is $65 \times 10^{2} \mathrm{~m}^{3}$, and barely covers the main tidal channels. The tidal prism at spring tides is about $80 \times 10^{2} \mathrm{~m}^{3}$, and more than doubles the water mass in the lagoon, covering the extensive tidal flats and salt marshes that constitute the majority of the lagoon area (Teixeira, 1994).

Early descriptions of possibly methane gas related phenomena in the lagoon area date back to the 1755 great Lisbon earthquake. The answers from local parishes to the Marquês de Pombal enquiries on the 1755 earthquake report that the Vouga river waters "boiled as if they were on fire" and that the waters from the Mira lagoon (at the south end of the Ria) "appeared to boil so hard that they would break at the lagoon shore as if they were sea waves" (Coelho, 2005; Oliveira, 2005); these tales may be explained by gas releases from seismically destabilized sediments.

The first unequivocal direct observations of escape of biogenic methane from several drill holes in Quaternary sediments from the area surrounding the Ria of Aveiro were reported by the Portuguese Geological Survey in 1967 (Faria et al., 1967). Since then, similar evidence has been observed in other land wells for water exploration. More recent investigations with chirp and boomer high resolution seismic data in tidal channels of the Ria de Aveiro (Pinheiro and Duarte, 2003a; Pinheiro and Duarte, 2003b; Pinheiro et al., 2003; Duarte et al., 2007; Duarte, 2009) have shown extensive acoustic evidence of gas accumulation and seepage, including acoustic turbidity, enhanced reflections, acoustic blanking, domes and acoustic plumes in the water column (flares).

The abundance of seismic data in the Ria of Aveiro, both in time and space allowed the quantitative investigation of the hypothesis that the tidal cycle affects the extent and distribution of seismic evidence of gas (Duarte et al., 2007; Duarte, 2009). Local changes in gas related seismic features as well as the data on amplitudes of the channel bottom reflections from the seismic profiles in the tidal channels of the Ria of Aveiro, provide very strong evidence that tides have an effect on the acoustic response of gas rich sediments (Figures 1 and 2; Duarte, 2009). In September of 2006, gas samples were collected from extensive bubble trains observed during falling tide in a docking pier ("Doca Pesca") in the Ria of Aveiro. The analysis of the gas samples composition by chromatography revealed that the gas was mostly methane (J. Coutinho, personal communication). The gas bubbling in the "Doca Pesca" pier showed a similar pattern with tidal altitude to the one between amplitude strengths and tidal altitude. The gas bubbling started with falling tide and petered down as the tide turned and rose. This independent observation supported the hypothesis that bubbling and gas escape in the Ria de Aveiro 